\title{
WOMEN'S RIGHTS UNDER UNIVERSAL PROTECTION AND INTERNATIONAL HUMAN RIGHTS TREATIES: DIALOGUES BETWEEN GLOBAL AND LOCAL
}

\author{
OS DIREITOS DA MULHER À LUZ DO SISTEMA UNIVERSAL \\ DE PROTEÇÃO E O POTENCIAL INTEGRADOR DOS TRATADOS \\ INTERNACIONAIS DE DIREITOS HUMANOS: DIÁLOGOS ENTRE O \\ GLOBAL E O LOCAL
}

Lara Santos Zangerolame Taroco ${ }^{1}$

Ana Cecília Sabbá Colares²

\begin{abstract}
The main international human rights documents establish gender equality as a right to be enforced. Nevertheless, this equality has remained purely formal. The task of transforming it into real equality has been arduous, especially because the historical construction of human rights has always occurred with the exclusion of women and the reinforcement of patriarchal ideologies. The result of this inequality is women's vulnerability, which directly affects the fulfillment of human rights. Therefore, the proper confrontation of the circumstances that give rise to women's vulnerability, linked to the promotion of gender equality policies, is essential for human rights international bodies enforcement. This study aims to discuss the main international treaty related to women's protection, the Convention on the Elimination of All Forms of Discrimination against Women (CEDAW), and to analyze how Brazilian legal system incorporates this treaty, which influences our domestic legal order.
\end{abstract}

KEYWORDS: Convention on the Elimination of all Forms of Discrimination Against Women. International Human Rights Treaties. Women's rights protection.

RESUMO: Os principais documentos internacionais de tutela dos direitos humanos estabelecem a igualdade como um direito a ser efetivado, tendo este sido proclamado em diversas declaraçóes. Nâo obstante, tal igualdade tem permanecido meramente formal, sendo árdua a tarefa de transformá-la em igualdade real entre mulheres e homens,

1 Mestranda em Direitos e Garantias Fundamentais pela Faculdade de Direito de Vitória - FDV. Graduada em Direito pela FDV, com intercâmbio semestral na Faculdade de Direito da Universidade de Coimbra (FDUC). Membro do Grupo de Pesquisa Teoria Crítica do Constitucionalismo do Programa de PósGraduaçăo Stricto Sensu da FDV. Advogada. larasantosz@hotmail.com

2 Mestre em Direito Internacional pela Universidade de Houston. Bacharel em Direito pela Pontíficia Universidade Católica do Rio de Janeiro (PUC-RJ). Membro da Associaçáo Internacional de Direito Penal. Advogada. anaceciliasabba@gmail.com 
principalmente quando se constata que a construçáo histórica dos direitos humanos sempre ocorreu com a exclusâo da mulher e o reforço de ideologias patriarcais. Oresultado desse desigual é a vulnerabilidade da mulher, advinda de um modelo de sociedade patriarcal, que afeta diretamente o cumprimento dos direitos humanos. Portanto, o devido enfrentamento das circunstâncias que propiciam a situaçâo de vulnerabilidade de mulheres, atrelado ao combate à desigualdade de gênero é essencial para o combate da discriminaçấo contra a mulher e consequente proteçâo dos direitos humanos, razâo pela qual é temática objeto de preocupaçăo de várias instâncias internacionais. Com base neste cenário, o presente estudo tem por objetivo apresentar os principais tratados internacionais relacionados com a proteçáo aos direitos das mulheres, em especial a Convençâo sobre Eliminaçâo de Todas as Formas de Discriminaçâo contra a Mulher, com vistas a analisar como estes tratados sâo recepcionados e como essas normas internacionais influem na conformaçâo do ordenamento jurídico brasileiro.

PALAVRAS-CHAVE: Convençâo sobre Eliminaçâo de Todas as Formas de Discriminaçāo contra a Mulher. Tratados Internacionais de Direitos Humanos. Proteçâo dos direitos da mulher.

\section{INTRODUCTION}

History has shown that to protect human rights is necessary to transcend borders and break certain principles, such as State absolute sovereignty. Since the World War II, a new period on the world's history has started. It is a period of global reflection, to reconsider old State structures, and to rebuild an international system able to promote human dignity.

States started to adhere to international human rights mechanisms. Brazil is part of this transition, mostly after its new Constitution from 1988, when the country became a democracy. Although before that Brazil had signed international treaties, due to political turbulences from the 1960s, 1970s, and 1980s, there was no coherent relation between Brazil's international position and its internal actions.

The frequent asked question is how the interaction between global and local occurred in Brazil, especially regarding the normative status of international treaties ratified by the president. This interaction is fundamental to this study. The place of core international human rights treaties within Brazilian legal system is fundamental to understand how legal practitioners apply human rights laws, and how women are being protected.

All core international human rights treaties claim gender equality. However, this equality is merely formal. Human rights historical construction has happened through women exclusion and reinforcement of patriarchal ideologies. It is a hard task to change this path and to transform it into real equality. This patriarchal model ${ }^{3}$ places women in a position of vulnerability, which direct affects human rights fulfillment. To combat this vulnerability is necessary to combat all forms of discrimination against this gender.

3 SPECTOR, Jessica. Prostitution and pornography: philosophical debate about the sex industry. Stanford: Stanford University Press, 2006, p.2-3. 
This research paper will introduce the core international treaty related to women's protection, the Convention on the Elimination of all Forms of Discrimination Against Women (CEDAW), and will analyze how Brazilian domestic law incorporates and applies such treaty.

\section{HUMAN RIGHTS AFTER WORLD WAR II AND HUMAN RIGHTS TREATIES UNDER THE BRAZILIAN 1988 COSTITUTION}

Throughout history, we can observe moments when consolidate achievements are questioned and denied. Some authors, such as Comparato ${ }^{4}$, defend that human beings occasionally need to suffer tragedies to learn a lesson. The major example to this theory is the World War II, which reflects what can happen when human rights lack protection. It was a time when humans where considered means to an end, not an end-in-itself, as it should be. ${ }^{5}$

At the end of the WWII, in a world affected by irreparable damages, it was necessary to overlook the past, to better understand mistakes humanity had done. However, there is no simple formula to predict the future catastrophes and to avoid them. What can be done is to understand causes and patterns of past events, to comprehend current problems and avoid relapse.

Internationalized protection of human rights was a response against the atrocities and horrors committed during the authoritarian regimes in Europe, specially the Third Reich. Presenting the State as the major violator of human rights, the Hitler Era was characterized by the destruction and expendability of human beings that resulted in the confinement of 18 million individuals in concentration camps, and the death of 11 million, including 6 million Jews. ${ }^{6}$

In front of these circumstances, the post world war II was a period for reflection. The State was the sole perpetrator of human rights atrocities, and States structures needed to be reviewed. Nazi State acts, although guided by a legal order that did not fulfill ethical and moral requirements, was covered by legality from the strict legal point of view, and many saw it as legitimate. ${ }^{7}$

In this context, the United Nations, in 1945, alongside with the Universal Declaration of Human Rights ${ }^{8}$ from 1948, started a new Era, characterized by the internationalization of human rights. This Era seeks not only to discipline reciprocal relations between States, but also individual relations under States' scope. The major role of the International Human Rights Law (IHRL) is to protect human beings in every aspect,

COMPARATO, Fábio Konder. A Afirmaçăo Histórica dos Direitos Humanos. 7. ed. Sâo Paulo: Saraiva, 2010, p. 38.

$5 \quad$ KANT, Immanuel. A metafísica dos Costumes. Lisboa: CalousteGulbenkian, 2005, p.56.

6 PIOVESAN, Flávia. Direitos Humanos e o Direito Constitucional Internacional. 13 ed., rev. e atual. Săo Paulo: Ed. Saraiva, 2012. p. 184

7 AGAMBEN, Giorgio. Estado de exceçăo. Sâo Paulo: Boitempo, 2004, p. 45.

8 PIOVESAN, Flávia. Direitos humanos e direito constitucional internacional. 11. ed. Săo Paulo: Saraiva, 2010, p. 28. 
encompassing civil and political rights, as well as social, economic, and cultural rights, ${ }^{9}$ during times of peace and war, apart from being man or woman.

It is generally considered among scholars that while the post WWII period was the time of human rights definition; the post cold war is the time of human rights implementation and enforcement. ${ }^{10}$ In Brazil, human rights protection started to become effective after the newly approved Constitution in 1988, when the country became a democracy again. The Constitution followed the growing internationalization of human rights, establishing "stretching mechanisms" to include other rights in the future. ${ }^{11}$

Although Brazil had signed some treaties in the previous years, due to the political crisis during the 1960s, 1970s, and part of the 1980s, the treaties did not reflect the internal situation and massive disrespect for human rights at the national level. The 1988 Constitution finished an authoritarian military regime in power since 1964. It was a milestone that secured a new democracy, and reflected a commitment to fundamental rights, essential to consolidate a democratic State.

The 1988 Constitution was also opened to the incorporation of human rights international bodies. According to article 5, paragraph 2: "the rights and guarantees expressed in this constitution do not exclude others deriving from the international treaties in which Brazil is a party." This constitutional provision opened a gap for international human rights treaties to be incorporated to our domestic legal system. It did not establish any special procedure as requirement for this incorporation.

The article 5, paragraph 3, was inserted by the constitutional amendment number 45, in 2004. This paragraph was added to the original text due to the broad discussion regarding the normative status of international human rights treaties. According to this new paragraph, human rights conventions and treaties approved by the two Houses of the Congress, by two shifts, with three fifths of the votes, will have the same status as constitutional amendments. Thus, these treaties are above ordinary laws.

Because the new paragraph 3 instated a proceeding though which the international human rights treaties should go through in order to be part of the Constitution, new disagreements emerged questioning the normative status of the treaties signed before the amendment, which did not go through the new required procedure.

However, some scholar ${ }^{12}$ expressed that this amendment was unnecessary. Paragraph 2 should be enough to give human rights treaties constitutional status. According to Cançado Trindade: "if this constitutional dispositive was given the correct application, we would have advanced towards the incorporation of human rights international protective norms to our domestic legal system." Furthermore, human

9 RAMOS, André de Carvalho. Curso de Direitos Humanos. 3.ed. Săo Paulo: Saraiva, 2016, p.148.

10 ZENOVIC, Predrag. Human Rights enforcement via peremptory norms - a challenge to state sovereignt. Riga: RGSL Research Papers, 2012, p. 5.

11 BONIFÁCIO, Artur Cortez. O Direito Constitucional Internacional e a proteçăo dos direito fundamentais. Săo Paulo. Método. 2008, p.45.

12 Cf. MOREIRA, Nelson. Direitos e garantias fundamentais e os tratados internacionais de direitos humanos. Belo Horizonte: Fórum, 2012. TRINDADE, Antônio Augusto Cançado. A proteçăo internacional dos direitos humanos e o Brasil. 2. ed. Brasília: Universidade de Brasília, 2000. PIOVESAN, Flávia. Direitos Humanos e o Direito Constitucional Internacional. 11. ed. São Paulo: Saraiva, 2010. 
rights could not be limited by Constitutional previsions because they cannot be guaranteed only by the State, the major human rights violator most of the time.

But due to incongruent interpretations, and divergent precedents, human rights treaties have distinct positions in our legal order. This, harms not only the congruence of the subject, but also complicates the enforcement of these international agreements, including the ones concerning women's rights, as this research paper will examine shortly.

\section{WOMEN'S RIGHTS UNDER HUMAN RIGHTS UNIVERSAL PROTECTION}

Promote gender equality is a requirement to fulfill women's rights. According to Jessica Spector: "a society that keeps women economically marginalized through education deprivation and job discrimination ensures a ready pool of women who will be vulnerable."13 This vulnerability comes from a model of patriarchal society, ${ }^{14}$ and affects women's lives in every aspect.

As a policy to promote gender equality, in 1946, the UN Economic and Social Council (ECOSOC) established the Commission on the Status of Women (CSW). The Commission meets annually to define and elaborate UN policies related to gender issues. ${ }^{15}$ In addition, this Commission is responsible to create annual reports and also to formulate recommendations to the ECOSOQ regarding emergency cases, which demand immediate actions.

Among the Conferences held since the Commission's creation, it is important to mention the results of the Fourth World Conference on Women, held in Beijing in 1995. The Conference created the Beijing Action Plan, composed of twelve strategies and two mega-strategies to achieve gender equality. The Commission is responsible to follow its implementation. 189 countries adopted the Action Plan unanimously. The Plan is an agenda for women empowerment and is considered the key global policy document on the issue. It sets strategies, objectives and actions in 12 critical areas of concern: women and poverty; education and training of women; women and health; violence against women; women and armed conflict; women and the economy; women in power and decision-making; institutional mechanism for the advancement of women; human rights of women; women and the media; women and the environment; the girl-child.

The adherence of member States to these policies is a challenge, but is not a harder task than the actual implementation. The Commission annual meetings are fundamental to maintain the agenda updated, to constant monitor the Beijing Action Plan enforcement, and to formulate evaluative reports regarding national measures.

13 SPECTOR, Jessica. Prostitution and pornography: philosophical debate about the sex industry. Stanford: Stanford University Press, 2006, p.20.

14 SPECTOR, Jessica. Prostitution and pornography: philosophical debate about the sex industry. Stanford: Stanford University Press, 2006, p.2-3.

15 TRUE, Mona Lena Krook Jacqui. Rethinking the life cycles of international norms: the United Nations and the global promotion of gender equality. European Journal of International Relations. Vol.18, Issue 1, 2010, p. 112. 
Besides the creation of the CSW, the universal system also has multilateral human rights treaties, such as the Convention on the Elimination of all Forms of Discrimination Against Women (CEDAW), the main international document on gender equality.

The resolution n.34/180 from the UN's General Assembly created the treaty. The convention counts with the Optional Protocol to the Convention, adopted by the UN General Assembly on October 6, 1999. The Protocol's goal is to monitor the Convention, enforcing the right to petition when a violation of a right protected by the Convention occurs. ${ }^{16}$ Before the proposal of the Optional Protocol, the Convention counted with a proceeding to prepare periodic reports as a monitoring mechanism.

States also recognize the competence of the Committee on the Elimination of Discrimination against Women to receive and consider communications from individuals or groups, under its jurisdiction, and from victims of any violation of the rights established by the Convention. ${ }^{17}$

For the Convention:

The term "discrimination against women" shall mean any distinction, exclusion or restriction made on the basis of sex which has the effect or purpose of impairing or nullifying the recognition, enjoyment or exercise by women, irrespective of their marital status, on a basis of equality of men and women, of human rights and fundamental freedoms in the political, economic, social, cultural, civil or any other field.

With this definition, all signatory States assume the commitment to eradicate gender discrimination, in the public and private spheres. On the article 2 of the Convention, States should "take all appropriate measures to eliminate discrimination against women by any person, organization or enterprise." Thus, it is clear that women's equality should apply to particular relationships also, and not only to the relation between women and State.

The Convention's obligations reflect a changing on sociocultural patterns regarding women's discrimination and inferiority. This is fundamental because discriminatory practices come from historical patriarchal conceptions, which permeates social relations. According to article 5, State members' need

To modify the social and cultural patterns of conduct of men and women, with a view to achieving the elimination of prejudices and customary and all other practices which are based on the idea of the inferiority or the superiority of either of the sexes or on stereotyped roles for men and women.

The Convention also expressed on article 10 the importance of appropriated policies to guarantee equality between men and women at the educational level. The member States shall promote:

(a) The same conditions for career and vocational guidance, for access to studies and for the achievement of diplomas in educational establishments of all categories in rural as well as in urban areas; this equality shall be ensured in pre-school, general, technical, professional and higher technical education, as well as in all types of vocational training;

16 RAMOS, André de Carvalho. Curso de Direitos Humanos. 3.ed. Sáo Paulo: Saraiva, 2016, p.184.

17 RAMOS, André de Carvalho. Curso de Direitos Humanos. 3.ed. Săo Paulo: Saraiva, 2016, p.184. 
(b) Access to the same curricula, the same examinations, teaching staff with qualifications of the same standard and school premises and equipment of the same quality;

(c) The elimination of any stereotyped concept of the roles of men and women at all levels and in all forms of education by encouraging coeducation and other types of education which will help to achieve this aim and, in particular, by the revision of textbooks and school programs and the adaptation of teaching methods;

(d) The same opportunities to benefit from scholarships and other study grants;

(e) The same opportunities for access to programs of continuing education, including adult and functional literacy programs, particularly those aimed at reducing, at the earliest possible time, any gap in education existing between men and women;

(f) The reduction of female student drop-out rates and the organization of programs for girls and women who have left school prematurely;

(g) The same Opportunities to participate actively in sports and physical education;

(h) Access to specific educational information to help to ensure the health and wellbeing of families, including information and advice on family planning.

These measures should also be applied to employment (article 11), to health care (article 12), and to all other aspects of economic and social life (article 13). All these articles intended the elaboration of political steps by member States to eliminate gender discrimination. It reinforces the importance of a dialogue between national and international law, in order to guarantee a broad protection of human rights at each level.

Therefore, it is important to comprehend how is the relation between the Brazilian legal system to human rights treaties regarding women protection, specially how was the incorporation of the CEDAW, and the Optional Protocol, in order to identify national measures resulted from these international dispositions.

\section{INTERNATIONAL HUMAN RIGHTS TREATIES AND WOMEN'S PROTECTION IN BRAZIL}

As previously stated, the practices in Brazil from the military government, from the 1960s until the 1980s, reflected a huge contradiction between Brazilian international standing point and internal disrespect for human rights. ${ }^{18}$ In addition, the military dictatorship blocked the incorporation of several human rights treaties. Covenants signed in 1966, such as the International Covenant on Economic, Social and Cultural Rights, as well as the International Covenant on Civil and Political Rights, were ratified only in 1992, after the end of the authoritarian regime.

The introduction of article 5, paragraph 2 in the Brazilian Constitution was a step to insert Brazil in the group of States that protect human rights effectively. According to this paragraph, rights and guarantees expressed in the 1988 Constitution do not

18 TRINDADE, Antônio Augusto Cançado. A proteçáo internacional dos direitos humanos e o Brasil. 2. ed. Brasília: Universidade de Brasília, 2000, p. 57-58. 
exclude other international treaties from which Brazil is part of. In other words, the paragraph 2 from the 1988 Constitution is a legal gap that opens the possibility of others human rights laws incorporation and application.

Accordingly, international human rights treaties relates to the constitutional text differently than other norms. Treaties can "coincide with the rights protected by the Constitution, integrate, complement, and assist the universe of constitutional rights, as well as contradict them."19 On this last hypothesis, a constitutional norm would be in conflict with a human rights law.

To understand the normative status of international human rights bodies within Brazilian law is fundamental to access what would occur in case of conflict. It is the only way to follow the classic criteria of legal norms conflict solution, which is: chronology, specialty, and hierarchic.

Currently, there are four theses regarding the hierarchical position of human rights treaties. The first one, considers human rights treaties above the Constitution, due to their high importance. According to Celso de Albuquerque Mello, the "international norm prevails against the constitutional norm, even though if a later Constitution tries to revoke the international norm."20

Conversely, the second thesis conceives human rights treaties as ordinary laws. On this perspective, they would have the same status as any other law from our domestic legal system, under the Constitution. The treaties would follow the same logic of these laws: the later norm revokes the previously one on the issue.

A third thesis defends the constitutionality of international human rights laws. According to these scholars, they would have constitutional status due to the subject relevance and the opening of the article 5, paragraph 2, of the Constitution. Thus, there would be no need to discuss conflict solution through the hierarchical criteria because the Constitution and international human rights treaties are norms of the same hierarchy. These scholars apply the victim centric approach, according to the inspirational source that moves the protective architecture of human rights. ${ }^{21}$ For Flavia Piovesan, this structure was created exactly to earn the best and most effective "protection for real victims and prevention of human rights violations." 22

But after the constitutional amendment n. 45/2004, international human rights treaties can only have constitutional status if observed the proceedings of the new paragraph 3 of the article 5 of the Constitution. However, the question remains: what about the treaties ratified previously to the amendment? Would they be under the Constitution, with status of ordinary law, or would they be constitutional due to its subject matter?

19 PIOVESAN, Flávia. Direitos Humanos e o Direito Constitucional Internacional. 11. ed. Sáo Paulo: Saraiva, 2010, p. 43.

20 MELLO, Celso D. de Albuquerque. $O \S^{\circ}$ do art. $5^{\circ}$ da Constituiçáo Federal. In: TORRES, Ricardo Lobo. Teoria dos Direitos Fundamentais. Sáo Paulo: Renovar, 1999, p. 25.

21 Flávia Piovesan no prefácio da obra: MOREIRA, Nelson Camatta. Direitos e garantias constitucionais e tratados internacionais de direitos humanos. Belo Horizonte: Fórum, 2012, p. 18.

22 Flávia Piovesan no prefácio da obra: MOREIRA, Nelson Camatta. Direitos e garantias constitucionais e tratados internacionais de direitos humanos. Belo Horizonte: Fórum, 2012, p. 18. 
The Supreme Court of Brazil adopted a fourth possibility. At this opportunity, the Minister Gilmar Mendes returned to the thesis of human rights supra-legality. ${ }^{23}$ According to this thesis, international human rights treaties would be under constitutional norms, but above ordinary laws. Until this judgment, the Supreme Court of Brazil had considered human rights treaties as having the same status of ordinary law, without any distinction between general international treaties and human rights treaties.

According to the Minister, human rights treaties that did not go through the procedural incorporation established by paragraph 3 cannot overthrow a constitutional norm. This is the case of the Inter-American Convention on Human Rights, which was ratified before this rule; as well as the Convention on the Elimination of all Forms of Discrimination Against Women, which came into force in 1984, and then, without reservations, in September 2002. However, these treaties could overthrow ordinary laws.

The Court considered only procedural questions, and did not considered the relevant material value of human rights laws. Nevertheless, some scholars ${ }^{24}$ still sustain that all international human rights treaties have constitutional status. According to Andre de Carvalho Ramos ${ }^{25}$ :

It is undeniable the constitutional status of international human rights treaties if we have in mind the article 1 of our Constitution (the rule of law, and human dignity as pillars of the Republic), as well as the article 5, paragraph 2 .

For Flavia Piovesan, "according to the paragraph 2 of the article 5, all human rights treaties are materially constitutional." 26 To this author, it is fundamental to recognize the criteria of the most favorable norm to the victim to solve eventual conflicts. Human rights treaties have the same protective intention of the 1988 Constitution.

It is also possible to recognize the constitutional status of the CEDAW to avoid inconsistences. Currently, human rights treaties have two different treatments. If they were incorporated before 2004, and followed the ordinary procedure, voted by simple majority, its norms are infra constitutional. If they were ratified after 2004, and followed the special procedure of the paragraph 3, these treaties have Constitutional status. Thus, it is possible that one human rights treaty would be superior to another one in the same subject. This does not sustain any congruence to human rights characteristics, such as universality, invisibility, and non-hierarchy.

As an example, the Convention on the Rights of Persons with Disabilities, a treaty that was incorporated by our legal system through the special procedure of the article 5, paragraph 3, it is hierarchically superior to the Convention on the Elimination of all Forms of Discrimination Against Women, and to all others human rights treaties previously to this norm, including the Inter-American Convention on Human Rights, when there is no such hierarchy between the rights they protect.

23 MOREIRA, Nelson. Direitos e garantias fundamentais e os tratados internacionais de direitos humanos. Belo Horizonte: Fórum, 2012, p.162.

24 PIOVESAN, Flávia. Direitos Humanos e o Direito Constitucional Internacional. 11. ed. Săo Paulo: Saraiva, 2010, p. 108.

25 RAMOS, André de Carvalho. Curso de Direitos Humanos. 3.ed. Săo Paulo: Saraiva, 2016, p.423.

26 PIOVESAN, Flávia. Direitos Humanos e o Direito Constitucional Internacional. 11. ed. Săo Paulo: Saraiva, 2010, p. 108. 
Human rights law, such as the Women Convention, cannot be viewed as a subsidiary source. It should be treated as standard norms to assess the constitutionality of other legal dispositions. To Michel Rosenfeld, ${ }^{27}$ the incompleteness and the permanent openness are inherent to the modern constitutional project, because: "a constitutional written text is incomplete not only because does not address all the subjects it should address, but because it is not able to consider exhaustively all issues that could rise from the subjects it addressed."

It is necessary to stop consider international human rights treaties a national matter ${ }^{28}$, always subordinated to the national law. This view empties the historical reasoning of these instruments to not trust human rights protection solely to States. In the specific case of the CEDAW, consider this instrument as a national issue also ignores women's historical marginalization worldwide.

Still, challenges regarding the Convention's implementation are many. But to consider its norms as constitutional law can be an important tool for female's advocacy. The inconsistency between the Convention, since first incorporated, in 1984, and the Brazilian Civil Code from 1916, which was in force until December 2002, can give us an example. The Civil Code considered married women as incapable to take any decision regarding her own life. It was a formal contraction to the part IV of the Convention, which ruled against women's legal incapacity, and other subjects related to marriage and family relations. This contradiction has never been challenged. Society evolved and this Civil Code is not longer in force. However, if the Convention norms had been considered constitutional since its first incorporation, jurists would have had more space to debate the constitutionality of the Civil Code.

The Convention also recommends affirmative actions, on a temporary character, to enforce the measures proposed. Following the CEDAW recommendation, the Brazilian law n. $9504 / 97$ established a minimum of $30 \%$ of women on each political party. This was adopted towards a greater representation of women within the politics, historically occupied by men.

This affirmative action is fundamental because without women's representation, women issues, such as abortion and birth control, will never be properly discussed or approved. Without female representation, women's perspectives to every aspect of life will never have the attention they deserve. It is a significant step because the political sphere is also a place for freedom and establishment of relations between equals. ${ }^{29}$ For a long time, this public domain was not part of women's world. The social conception stood that "proper women do not talk about politics; it is inconvenient and rude." 30

Slowly, this paradigm is being transformed, and affirmative actions can expedite this change. The actual scenario still structures a model that is excluding, and tends to benefit men. In order to have gender equality and respect for women's rights, we need to transform this reality. Law can be an important tool for this process. A process entrenched in women's rights universalization, as well as nationalization.

27 ROSENFELD, Michel. A identidade do sujeito constitucional. Belo Horizonte: Mandamentos, 2003 , p. 50.

28 RAMOS, André de Carvalho. Curso de Direitos Humanos. 3.ed. Sâo Paulo: Saraiva, 2016, p. 433.

29 ARENDT, Hannah. A Condiçăo Humana. 9. ed. Rio de Janeiro: Forense Universitária, 1999, p.62.

30 PERROT, Michelle. Mulheres ou os silêncios da História. 1. ed. Săo Paulo: EDUSC, 2009. p. 464. 


\section{FINAL CONSIDERATIONS}

First, this research paper aimed to explain how the historical affirmation of human rights occurred, considering the post World War II scenario as a landmark that requested change within the structure of International Law, and mostly, within Human Rights Law. Significant internal transformations within States echoes at the international law, and new international frameworks reflect at the domestic level. ${ }^{31}$

The post WWII requested States re-structuration. They could no longer be considered as islands that have minimum relations with other States. Human rights affirmation requires constant cooperation, as well as treaties reception and incorporation. The several transformations at the global level created the necessity to construct something new at the national level, a constitutionalism opened to the internationalization of human rights protection. International law has superseded boarder of States, and it is now "relevant to other legal orders, including non-State actors."

In this scenario, international women's rights protection has special importance. It constitutes a necessary condition for gender equality enforcement, so asserted throughout several international documents. The Women Convention, after integrated to our domestic legal system, according to the Supreme Court of Brazil, has the same status and effect of infra-constitutional norms.

However, for important scholars, the article 5, paragraph 2, of the 1988 Constitution permits a different interpretation. According to them, international human rights treaties would be incorporated immediately by our Constitution. They would have instantly constitutional status, differently from other treaties, which would be subjected to the procedure established by the amendment 45/2004.

To eliminate discrimination and to secure gender equality, the CEDAW is composed by a preamble and thirty articles divided in six different parts. On the introduction, the document reminds that women discrimination violates the principle of equality and the respect for human dignity. It does not matter if this discrimination occurs at the political, social, economic, or cultural sphere. It constitutes "an obstacle to the fulfillment of society and family well-being and obstructs the development of women's potentialities to serve her country and her community." International law as well as national law shall promote combat gender discrimination.

Finally, a written constitution cannot exhaustively address all issues that could rise from individual relations within the State's scope. Therefore, a constitutional legal order needs to use other sources to enrich itself. To promote equality, the Convention on the Elimination of all Forms of Discrimination Against Women is one of these sources. The Convention deserves a more prevalent role at our domestic legal system.

31 TRINDADE, Antônio Augusto Cançado. A proteçâo internacional dos direitos humanos e o Brasil. 2. ed. Brasília: Universidade de Brasília, 2000, p. 35. 


\section{REFERENCES}

AGAMBEN, Giorgio. Estado de exceçâo. Sâo Paulo: Boitempo, 2004.

ARENDT, Hannah. A Condiçâo Humana. 9. ed. Rio de Janeiro: Forense Universitária, 1999.

ARENDT, Hannah. Origens do totalitarismo: anti-semitismo, imperialismo, totalitarismo. Sâo Paulo: Companhia das Letras, 2011.

BONIFÁCIO, Artur Cortez. O Direito Constitucional Internacional e a proteçâo dos direito fundamentais. Săo Paulo. Método. 2008.

CABRAL, Karina Melissa. Direito da mulher: de acordo com o Novo Código Civil. 1. ed. Săo Paulo: Editora de Direito, 2004.

COMPARATO, Fábio Konder. A Afirmaçāo Histórica dos Direitos Humanos. 7. ed. Săo Paulo: Saraiva, 2010.

GARDENS, Kew. O status intelectual da mulher. Săo Paulo: Paz e Terra, 1977.

HABERMAS, Jürgen. A constelaçâo pós-nacional: ensaios políticos. Săo Paulo: LitteraMundi, 2002.

HOBSBAWN, Eric. Sobre história. Săo Paulo: Companhia das Letras, 2000.

KANT, Immanuel. A metafísica dos Costumes. Lisboa: CalousteGulbenkian, 2005.

MARTINS-COSTA, Judith. Os direitos fundamentais e a opçăo culturalista do novo Código Civil. In: SARLET, Ingo Wolfgang (org.). Constituiçâo, Direitos Fundamentais e Direito Privado. Revista e Ampliada. 3. ed. Porto Alegre: Livraria do Advogado, 2010.

MELLO, Celso D. de Albuquerque. Direito constitucional internacional. 2. ed. Săo Paulo: Renovar, 2000.

MELLO, Celso D. de Albuquerque. O $2^{\circ}$ do art. $5^{\circ}$ da Constituiçăo Federal. In: TORRES, Ricardo Lobo. Teoria dos Direitos Fundamentais. Sáo Paulo: Renovar, 1999.

MOREIRA, Nelson. Direitos e garantias fundamentais e os tratados internacionais de direitos humanos. Belo Horizonte: Fórum, 2012.

PERROT, Michelle. Mulheres ou os silêncios da História. 1. ed. Sáo Paulo: EDUSC, 2009. 
PIOVESAN, Flávia. Direitos humanos e direito constitucional internacional. 11. ed. Sáo Paulo: Saraiva, 2010.

RAMOS, André de Carvalho. Curso de Direitos Humanos. 3.ed. Săo Paulo: Saraiva, 2016.

REZEK, Francisco. Direito Internacional Público. 14. ed. Săo Paulo: Saraiva, 2013.

ROSENFELD, Michel. A identidade do sujeito constitucional. Belo Horizonte: Mandamentos, 2003.

SCHAFRANSKI, Silvia Maria Derbli. Direitos Humanos e seu processo de universalizaçāo: análise da Convençâo Americana. Curitiba: Juruá, 2003.

SPECTOR, Jessica. Prostitution and pornography: philosophical debate about the sex industry. Stanford: Stanford University Press, 2006.

TRINDADE, Antônio Augusto Cançado. A proteçâo internacional dos direitos humanos e o Brasil. 2.ed. Brasília: Universidade de Brasília, 2000.

TRINDADE, José Daminhăo de Lima. História social dos direitos humanos. 3. ed. Sáo Paulo: Peirópolis, 2011.

TRUE, Mona Lena Krook Jacqui. Rethinking the life cycles of international norms: the United Nations and the global promotion of gender equality. European Journal of International Relations. Vol.18, Issue 1, 2010.

VIEIRA, Oscar Vilhena. Globalizaçâo e constituiçâo republicana. Direitos humanos, globalizaçâo econômica e integraçâo regional: desafios do direito constitucional internacional.Săo Paulo. Max Limonad. 2002.

ZENOVIC, Predrag. Human Rights enforcement via peremptory norms - a challenge to state sovereignt. Riga: RGSL Research Papers, 2012. 